\section{Data protection and bioethics initiatives \\ will seek backing}

[LONDON] Delegates attending the World Conference on Science could be asked to endorse the creation of a "universally acceptable legal framework" that would protect access to scientific information "that takes into account the interests of all links in the scientific information chain".

They may also be asked to support closer links between science and other systems of and approaches to knowledge "for their mutual enrichment and benefit". And Unesco's committee on bioethics, which has already produced a statement on protecting the human genome, could be asked to extend its activities to other genomes to prevent "exclusivity in the control of life processes".

These are among the suggestions in a preliminary draft of the Science Agenda Framework for Action, which delegates will be asked to agree to at the conference. The document is intended to indicate specific ways of putting into effect the conclusions of a parallel document, Declaration on Science and the Use of Scientific Knowledge, which the delegates will also be asked to adopt.

The Agenda is controversial. Some delegates who have seen the draft claim it is long on rhetoric but short on practical proposals, and omits any reference to, for example, the need to support particular disciplines and to encourage excellence in science. But Unesco officials point out that the draft will probably be significantly revised before the final version is submitted to the conference.

The full text of the draft Agenda is on http://helix.nature.com/wcs/m00f.html. The text of the draft of the Declaration on Science that will accompany it can be found on http://helix.nature.com/wcs/m00s.html Full text: http://imagine.nature.com/wcs/a21.html

\title{
British plan to train science journalists from the South
}

[LONDON] Two British organizations are proposing to open an International Centre for the Communication of Science, to train science journalists, broadcasters and exhibition organizers from developing countries.

The plan is being drawn up by the Science Museum and the British Association for the Advancement of Science, which have a long tradition of communicating science to the public. The centre would be based in a building devoted to public debate on science that they are already planning to construct and occupy jointly on the museum's land in South Kensington, London.

The proposal to add an international centre to the plans was endorsed last week by Federico Mayor, director-general of the United Nations Educational, Scientific and Cultural Organization (Unesco). At a meeting held at the museum to present plans for the World Conference on Science, Mayor told those responsible for the idea that "you can count on the full support of Unesco".

Unesco officials say that such a centre would fit in well with a strategy that they are keen to see endorsed at the conference. This is to identify centres of excellence in developed countries which can offer to those from developing countries intensive training courses in specific skills or areas of knowledge.

"We would very much like to see several proposals along these lines endorsed in Budapest," says Maurizio Iaccarino, Unesco's assistant director-general for science.

The proposal for the London centre emerged during discussions last year between Iaccarino, John Durant, assistant director for communication at the Science Museum, and Peter Briggs, executive secretary of the British Association.

"The agenda of the world conference stresses the need to set up a constructive dialogue on the ways in which science has an impact on society," says Durant. "We feel that our idea fits the category of 'modest and realistic proposals' that many people argue need to be on the table in Budapest." Full text: http:/ /imagine.nature.com/wcs/a18.html

\section{Africans team up to boost basic research}

[LONDON] Science faculties from universities in six countries in East and Southern Africa have agreed to form a network to help develop research and higher education in poorer parts of the continent.

The network will comprise initially universities in Tanzania, Kenya, Zambia, Zimbabwe, Botswana and Swaziland. The project was proposed by Mayunga Nkunya, dean of the science faculty at the University of Dar es Salaam in Tanzania. It was announced at a conference on sciences for development held in Arusha, Tanzania.

Nkunya says many scientists see little point in doing research while their countries remain mired in poverty, military conflict and political instability. The network will give help and mentoring to staff and students in universities.

The Arusha conference promoted the idea that investment in research is a key to development, and resolved to emphasize this message at the world conference. Full text: http://imagine.nature.com/wos/a11.htm

\section{Japan's candidate for Unesco top job promises efficiency drive}

[PARIS] Japan is bidding to play a more public role in international affairs. The government has nominated Koichiro Matsuura, its ambassador to France, as a candidate for the soon-to-be-vacant post of director-general of Unesco.

Matsuura is widely considered to be one of the three front-runners for the job. He is not offering a radical reform of the role of the agency, but more efficient delivery of its existing programme, with greater emphasis on education. But he says he aims to be "realistically ambitious" in his aims and

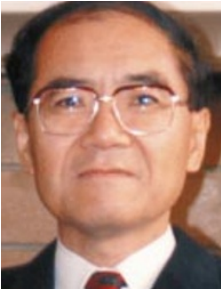

Matsuura: Unesco needs US support. needs US support. the apparent absence of a grandiose vision will inspire support from developing

objectives for the organization.

This approach is likely to appeal to some of the agency's Western donors, particularly those keen to increase the cost-effectiveness with which their contributions are used. Less certain is whether Æิㄷ 1999 Macmillan Magazines Ltd countries which frequently like to see Unesco as a champion of their grievances.

In an interview with Nature, Matsuura said that, if elected, his priorities for Unesco would be a more efficient bureaucracy and enhanced efforts to persuade the United States to rejoin the organization. "US reentry is very important," says Matsuura. "We cannot hope to have meaningful discussions - for example about issues related to science - without the United States as an active participant." Full text: http://helix.nature.com/wcs/c10.html 